\title{
TELL (Technology-enhanced Language Learning) in Iranian High Schools: A Panacea for Emotional and Motivational Detriments
}

\author{
Afsaneh Ghanizadeh*, Azam Razavi, Akram Hosseini \\ Imam Reza International University, Mashhad, Iran \\ Corresponding Author: Afsaneh Ghanizadeh, E-mail: a.ghanizadeh@imamreza.ac.in
}

\section{ARTICLE INFO}

Article history

Received: January 23, 2018

Accepted: March 26, 2018

Published: July 01, 2018

Volume: 7 Issue: 4

Advance access: May 2018

Conflicts of interest: None

Funding: None

\begin{abstract}
Recent expansions in technological tools are shifting the direction of foreign-language education. A plethora of EFL research studies suggested that the benefits of TELL (technology-enhanced language learning) embrace a wide array of cognitive, motivational, and emotional attributes. English language teaching in Iran has recently undergone a host of rapid changes. The most apparent change was that the traditional grammar-based instruction left its place to communicativeoriented approaches. As a result, teachers needed extra aids to provide learners with the desired environments and foster exposure to authentic materials. In this regard, multimedia techniques (MTs) offer wide range of facilities in high speed and effective information processing. The purpose of this study was to examine the possible impact of MTs in high schools on students' L2 learning attitudes, anxiety, and language proficiency. To do so, the researchers adopted a mixed-methods design integrating experimental and interview analyses. The sample of the study consisted of 124 female students from Motahhareh high school in Mashhad, a city in Northeast of Iran. Twelve items out of Dörnyei's L2 Motivational Self- system scale were picked to measure attitudes to L2 learning and L2 anxiety. The Babel test was employed for gauging participants' language proficiency. The sample was divided into two experimental and two control groups. The participants in experimental and control groups were provided with the same materials and instruction. The point of difference lay in the mode of presenting the materials in experimental group, i.e. via multimedia techniques. In the second phase, a semi-structured interview was conducted with a number of students in experimental groups to delve into their attitudes and feedbacks concerning MT-based instruction. The results indicated that there were statistically significant differences in students' L2 learning attitudes, anxiety, and language proficiency in favor of the experimental group. In the light of the obtained results, the study presented a number of practical and accessible recommendations for implementing multimedia in teaching English.
\end{abstract}

Key words: Multimedia techniques, Mixed-methods design, Language proficiency, Attitudes, Anxiety

\section{INTRODUCTION}

Teaching and learning in academic domain are developing ever increasingly over the last decade. Active learning constituted the cornerstone of education in this era of academic change. "Active learning" incorporates a broad cluster of practices, group work or collaborative learning, negotiation of meaning, and technology-based tasks and activities. Different research studies suggest when students are actively involved in the process of learning they learn more effectively (Davis, 1993). Moreover, Wasley (2006) stated that, "Students who participate in collaborative learning and educational activities outside the classroom and who interact more via technological tools get better grades, are more satisfied with their education, and are more likely to remain in college" (p. 39). A synergistic learning environment, as opposed to an inert learning context, facilitates effective learning (Murphy, Mahoney, Chen, Mendoza-Diaz, \& Yang, 2005).

During 1990's, the use of various media expanded immensely and then the era of multimedia technologies (MTs) emerged (Ramaiah, 1998). With the fast development of science and innovation, the utilization of multimedia technology in teaching has provided a favorable setting for learners. Multimedia technology highlights integrating and manipulating of data using graphics, texts, video, images, and animation effect in the classrooms (Rana, 2013). According to Rana (2013), "teachers need to stop following the same old ways of teaching and experiment and acknowledge that the world is changing and we need education that augments that change" (p. 10). Consequently, it is imperative for language educators to be cognizant of the most recent and accessible tools and know what is appropriate in any given circumstances. Brooks 
(1997) defined multimedia technologies as combined use of different media, such as music, videos, slides, and lighting, especially for the purpose of education or entertainment.

Despite the endeavors of some researchers in multimedia learning and the resultant instructional motivation (e.g., Astleitner \& Hufnagl, 2003; Keller \& Suzuki, 2004; Song \& Keller, 2001), findings are not very consistent. Hahne, Benndorf, Frey, and Herzig (2005) conducted a well-controlled study with online evaluation. Findings indicated that although students displayed favorable attitudes towards computer-based learning $(\mathrm{CBL})$ at the onset, this feeling did not endure till the end of course, and learning outcomes were highly under the influence of students' prior knowledge rater than their CBL use. Moreover, another study done by Hardré, Crowson, Xie, and Ly (2007) explored the data quality of questionnaire administration. Results showed that the paper-based group was better than both computer-based and web-based groups, and the affective responses of participants favored the paper-based mode over computer- and web-based modes. Their finding implied that utilization of multimedia technologies does not necessarily lead to high motivation of learners. Another study by Hoskins and Van Hooff (2005) about Web Course Tools (WebCT) found that only those students already highly-motivated and academically-able benefited from bulletin board use, suggesting that motivation and academic ability are determinants of achievement in hypermedia learning.

In the domain of language learning, Atiyyat (1995) conducted a study to explore the impact of multimedia technologies on English vocabulary learning and retention. The results substantiated the efficiency of MTs in both vocabulary learning and retention.

In addition, Warschauer (1997) suggested that multimedia technologies can create a relaxing and non-threatening environment for learners in which their motivation and self-esteem can be promoted and their anxiety can be reduced. Mayer (2001) recommended that when EFL learners establish connections between words and pictures than from words or pictures alone, they are able to create a more profound comprehension of words. In other words, using multimedia technologies in EFL classes can make communication and learning more effective (Al-Seghayer, 2001). Moreover, MT via its visual and verbal presentation activate cognitive processing (Mayer \& Moreno, 2003).

More recently, Rostami, Akbari, and Ghanizadeh (2014) corroborated the positive role of Smart Schools exposing students to smart boards, Power Point Presentation, and World Wide in enhancing EFL learners' reading comprehension and the retention of reading materials.

In a study, Ghanizadeh and Razavi (2015) probed the impact of using multimedia in English high school classes on students' language achievement and goal orientations (mastery, performance, and avoidance). The findings indicated that using multimedia elements has a positive and significant influence on learners' language achievement as well as on the adaptation of mastery goals focusing on task-based or intrapersonal competence.

Ghanizadeh, Razavi, and Jahedizadeh (2015) carried out a meta analysis by reviewing recent studies in technology-en- hanced learning (TELL). The results demonstrated that the benefits of technology in language classes are multidimensional and comprehensive encompassing cognitive, met cognitive, and affective domains of learning.

So as can be seen, the advantages of multimedia over more traditional tools can unquestionably be found in its facility to present vast amount of information at reasonable cost and in its developed search functions. In L2 learning domain, the application of multimedia technology has beneficial purposes as cultivating students' interest, promoting students' communication capacity, widening students' knowledge, and providing an insightful understanding of the target culture.

To sum up, the researchers assert that the studies presented in this section demonstrate a valid corroboration of the efficiency of multimedia input. The current study differs from the previous studies because it pivots around different aspects of English teaching according to MTs.

Over the last few years, English language teaching has embraced many rapid changes in Iran. Seemingly, as the result of one of these transformations traditional teacher-fronted approaches with the core attention to grammar and deductive leaning gave its way to communicative-oriented approaches. Communicative approaches revolve around the authentic language use, active participation, interaction and contextualized language (Warschauer, 2000). This entails providing learners with authentic language use and contextualized forms. In line with this requirement, the advent of new technological facilities in the foreign language teaching expedited the prospects of attaining the objectives of communicative language teachinh. Thus, with the weight of responsibility falling on the teachers and their work, the incorporation of MTs to language classes will play a facilitative role. It can assist teachers and teacher preparation programs move forward and guide them in raising the quality use of new methods of teaching English in Iran. It can also be argued that the integration of multimedia programs merging sounds and movement makes it natural to synchronize listening, speaking, reading, and writing in a single activity (Warschauer \& Healay, 1998).

This study will set specific suggestions regarding the integration of technology into curriculum development and teaching materials. In addition, it offers ideas for appropriate development and use of teaching materials as well as practical classroom applications.

Based on the above introduction on MTs, The following research questions were posed and investigated in this study:

1. Does the application of MTs influence on student's language proficiency in high school English classes?

2. Does the application of MTs influence on high school students' attitudes to learning English language?

3. Does the application of MTs influence on students' anxiety in learning English?

4. What are high school students' attitudes toward MTs?

\section{METHODOLOGY}

The purpose of this study was to examine the impact of teaching English through MTs on students' L2 learning attitudes, anxiety, and language proficiency. In addition, the 
researcher employed a semi-structured interview to delve into students' attitudes to MT.

\section{Participants}

Participants in this study were students in grade nine in Motahhareh high school, a north urban setting in Mashhad, one of the cities of Khorasan Razavi in Iran. They were female students and all aged between 14 and 15. The school was chosen because it was equipped with various facilities and spacious classrooms. It was expected that such accommodations would facilitate the implementation of the present research.

The participants were divided into four classes according to their language scores in grade eight of high schools. Randomly, the researcher selected two classes as control and two as experimental groups. The participants consisted of a total number of 124 students, 62 in experimental groups and 62 in control groups. They all had the same exposure to English through formal classes in grade seven and eight in high school. Of course, to ensure homogeneity of participants of the two groups, a Babel proficiency test was administered.

\section{Instruments}

Two instruments were utilized in the current study as follows:

\section{The Dörnyei's L2 motivational self-system questionnaire}

To determine the impact of teaching English through MT on students' L2 learning attitudes and anxiety, the researchers utilized Dörnyei's (2005) L2 Motivational Self-system Questionnaire. The Persian version of the questionnaire translated and validated by Papi (2010) was utilized in the present study. The questionnaire contained two main parts: One part measured learners' attitudes and motivation toward learning English and the other part measured learners' anxiety. The items were of statement and question types; a six-point rating scale was used to measure with "not at all" anchoring at one end and "very much" anchoring at the other end.

Attitudes to learning English (six items): It deals with "situation-specific motives related to their immediate learning environment and experience" (Taguchi, Magid, \&Papi, 2009 , p. 75, as cited in Rostami \& Ghanizadeh, 2015). Internal consistency reliability coefficients of the items computed via Cronbach's Alpha was reported to be. 65 .

L2 Anxiety (six items): It is conceived as 'the feeling of tension and apprehension specifically associated with second language contexts, including speaking, listening and learning Internal consistency reliability coefficients of the items computed via Cronbach's Alpha was reported to be.85 (Taguchi, Magid, \&Papi, 2009, p. 75, as cited in Rostami \& Ghanizadeh, 2015).

\section{The Babel English language placement test}

In order to determine students' language proficiency level, the researchers used the Babel test, as a pretest and posttest. It is designed for rapid placement testing. The Babel English Language Placement Tests were closely based on the Nelson
Quick check Placement Tests. The tests were designed for ease of administrability in observing stringent test design standards. The tests were in multiple-choice format and consisted of items measuring the recognition of correct responses to reading prompts, grammatical forms and lexical choices in context.

\section{Procedure}

The study was conducted over twenty -two sessions between December and March 2016. The participants were Motahhareh high school students in grade nine in Mashhad. The participants in experimental and control groups were provided with the same materials (the official textbook, i.e., prospect) and instruction. The point of difference lay in the mode of presenting materials in experimental group, i.e., via multimedia technique. The participants in the experimental groups comprising 62 students were introduced to multimedia teaching program. The program was a package that exposed learners to a variety of animations, cartoons, PowerPoint programs, songs, electronic stories in the form of text, graphics, videos and sound, all of which were selected according to the tenets of CLT. The time of instruction for control and experimental groups was also identical, i.e., two sessions weekly, forty-five minutes each and lasted for three months. The participants in the experimental and control groups had a pre-test (including English proficiency test, L2 learning attitudes, and anxiety scales) before the treatment began. At the end of the treatment, a post-test was administered to both groups. This phase employed a pre-test, a treatment, a post-test. Finally, a number of participants of the experimental group sat for an interview to unlace their attitudes towards their experience in the class. The design of the study is presented in Table 1.

In the present study, the researchers used multimedia materials as well as supplementary aids as comprehensible

Table 1. The design of the study

\begin{tabular}{l}
\hline Stage/activity \\
\hline Pre-test \\
\hline a) Checking out the student's language proficiency at the \\
beginning of the experiment in all groups through the Babel Test \\
b) Checking out the student' attitudes and anxiety toward \\
language learning at the beginning of the experiment in all \\
groups through the Dornyei's L2 Motivational Self- system \\
Questionnaire.
\end{tabular}

\section{Treatment}

Implementing MTs in the experimental groups

\section{Post-test}

a) Checking out the student's language proficiency at the end of the experiment in all groups through the Babel Test b) Checking out the student' attitudes and anxiety toward language learning at the end of the experiment in all groups through the Dornyei's L2 Motivational Self- system Questionnaire.

\section{Interview}

Exploring the attitudes of participants in experiment group regarding MTs 
input to make English teaching process more effective and enjoyable. In so doing, a practical "three-step" method was posed. In the followings, the researchers delineate the procedure employed in integrating MTs to language classes.

Step 1: Giving comprehensible input

Interest is the most powerful motivation in students' learning. Therefore, according to the real context and needs, the teacher used some interesting pictures, audio links, PowerPoint shows, animations, short films, and other forms of multimedia materials as supplementary aids to teach the functions of the book.

Compared with the information written on the blackboard, in the book, or expressed by teacher, these vivid and colorful pictures and multimedia materials were very attractive and students' attention could strongly be attracted.

Step 2: Producing comprehensible output

Technology-based activities with their focus on social interaction and negotiation of meaning can be ideal aids to producing comprehensible output. So, each week one group of students generated a PowerPoint, text, a short film, or other forms of multimedia with the content being chosen by the learner from a previous lesson worked in the class. The teacher corrected the projects; the learners then presented their project and shared it with the others in the class. This implies that every week, there was a different speaking activity generated by the learners.

One of the researchers as the teacher of the class guided the students to do their project by introducing different sites such as, www.English for kids, www.pumpkings,www.easy English, which made it easy to download or have access to different videos, cartoons, and worksheets. Students collaborated on preparing for the presentation by using different information they gathered from different sites. Then they could present their projects in groups or individually. After gaining permission from the learners, the teacher typically shared the work they composed with the Tabadkan English group site (www.Tabadkan.English group.com).

Step3: Having role play

According to different functions of the book, at the end of each unit, the students in experimental groups did a role-play which displayed their ability in a simulated situation for real communication.

\section{RESULTS}

\section{The Results of Pretest on Language Proficiency}

To examine whether there is any significant difference between control and experimental groups regarding their English proficiency level, an independent samples $t$-test was run. As Table 2 shows, the mean scores of proficiency across groups are different: control $(M=10.19, S D=2.98)$, experimental $(M=10.44, S D=3.33)$. In other words, students in experimental group gained higher scores on proficiency test.

To see whether this observed difference is statistically significant, an independent samples $t$-test was run. Table 3 presents the results of $t$-test run on English proficiency level.
As can be seen, there is not a statistically significant between the two groups regarding the degree of their proficiency $(t=-.442, p<.05)$. In other words, the two groups are homogenous regarding their English proficiency level before the study.

\section{The Results of Pretest on Attitudes to Language Learning}

As Table 4 below shows, the mean scores of attitudes across participants in groups are different: control $(M=11.96$, $S D=1.87)$, experimental $(M=11.35, S D=2.08)$. In other words, students in control groups gained higher scores on attitude test.

Table 5 presents the results of $t$-test run on attitudes level. As can be seen, there is not a statistically significant between the two groups regarding the degree of their attitudes level $(t=1.72, p<.05)$. In other words, the two groups are homogenous regarding their attitudes level before the study.

Table 2. Descriptive statistics of English proficiency level across control and experimental groups

\begin{tabular}{lcccc}
\hline & N & Mean & $\begin{array}{c}\text { Standard } \\
\text { deviation }\end{array}$ & $\begin{array}{c}\text { Standard } \\
\text { error mean }\end{array}$ \\
\hline $\begin{array}{l}\text { Pre-test } \\
\text { proficiency }\end{array}$ & & & & \\
$\quad$ Control & 62 & 10.1935 & 2.98542 & 0.37915 \\
$\quad$ Experimental & 62 & 10.4483 & 3.33073 & 0.43735 \\
\hline
\end{tabular}

Table 3. Independent samples t-test showing the results of pretest on english proficiency

\begin{tabular}{lccccc}
\hline & t & df & $\begin{array}{c}\text { Sig. } \\
\text { (2-tailed) }\end{array}$ & $\begin{array}{c}\text { Mean } \\
\text { difference }\end{array}$ & $\begin{array}{c}\text { Standard } \\
\text { error } \\
\text { difference }\end{array}$ \\
\hline $\begin{array}{l}\text { Pre-test } \\
\text { proficiency }\end{array}$ & -0.442 & 122 & 0.660 & -0.25473 & 0.57670 \\
\hline
\end{tabular}

Table 4. Descriptive statistics of attitudes level across control and experimental groups in pretest

\begin{tabular}{lcccc}
\hline & N & Mean & $\begin{array}{c}\text { Standard } \\
\text { deviation }\end{array}$ & $\begin{array}{c}\text { Standard } \\
\text { error mean }\end{array}$ \\
\hline Pre-test attitudes & & & & \\
Control & 62 & 11.9677 & 1.87274 & 0.23784 \\
Experimental & 62 & 11.3548 & 2.08898 & 0.26530 \\
\hline
\end{tabular}

Table 5. Independent samples t-test showing the results of pretest on student's attitudes

\begin{tabular}{lccccc}
\hline & $\mathbf{t}$ & $\mathbf{d f}$ & $\begin{array}{c}\text { Sig. } \\
\text { (2-tailed) }\end{array}$ & $\begin{array}{c}\text { Mean } \\
\text { difference }\end{array}$ & $\begin{array}{c}\text { Standard } \\
\text { error } \\
\text { difference }\end{array}$ \\
\hline $\begin{array}{l}\text { Pre-test } \\
\text { attitudes }\end{array}$ & 1.720 & 122 & 0.088 & 0.61290 & 0.35630 \\
\hline
\end{tabular}




\section{The Results of Pretest on L2 Anxiety}

To check whether there is any significant difference between control and experimental groups regarding their anxiety level before implementing the treatment, an independent samples $t$-test was run. As Table 6 indicates, control $(M=29.9$, $S D=2.47)$, experimental $(M=30.58, S D=2.68)$.so, experimental groups have higher anxiety level than control groups in pre-test.

Table 7 presents the results of $t$-test run on L2 anxiety level. As table shows, there is not a statistically significant between the two groups regarding the degree of their anxiety level $(t=-1.42, p<.05)$. In other words, the two groups are homogenous regarding their attitudes level before the study.

\section{The Results of Posttest on Language Proficiency}

To investigate the effect of multimedia on student's language proficiency, the multimedia elements such as, animation, cartoons and PPP presentations were utilized in the experimental groups. The means of the both groups in the post-test were calculated. As it can be seen in Table 8, the mean of the experimental groups is $21.96(\mathrm{M}=21.96)$, and that of the control groups is 10.79 , $(\mathrm{M}=10.79)$.

As the results of independent-samples $t$-test are represented in Table 9, there is a statistically significant difference between experimental and control groups $(t=-16.97, p<.01)$. The effect size calculated via Cohens' $d$ was found to be 3.11 which is a large value according to Cohens' index value. In

Table 6. Descriptive statistics of anxiety level across control and experimental groups in pretest

\begin{tabular}{lcccc}
\hline & N & Mean & $\begin{array}{c}\text { Standard } \\
\text { deviation }\end{array}$ & $\begin{array}{c}\text { Standard } \\
\text { error } \\
\text { mean }\end{array}$ \\
\hline $\begin{array}{l}\text { Pre-test anxiety } \\
\text { Control }\end{array}$ & 62 & 29.91 & 2.47 & 0.31 \\
Experimental & 62 & 30.58 & 2.47 & 0.34 \\
\hline
\end{tabular}

Table 7. Independent samples t-test showing the results of pretest on student's anxiety

\begin{tabular}{lccccc}
\hline & $\mathbf{t}$ & $\mathbf{d f}$ & $\begin{array}{c}\text { Sig. } \\
\text { (2-tailed) }\end{array}$ & $\begin{array}{c}\text { Mean } \\
\text { difference }\end{array}$ & $\begin{array}{c}\text { Standard } \\
\text { error } \\
\text { difference }\end{array}$ \\
\hline $\begin{array}{l}\text { Pre test } \\
\text { anxiety }\end{array}$ & -1.42 & 122 & 0.15 & -0.66 & 0.46 \\
\hline
\end{tabular}

Table 8. Descriptive statistics of English proficiency level across control and experimental groups in post- test

\begin{tabular}{lcccc}
\hline & N & Mean & $\begin{array}{c}\text { Standard } \\
\text { deviation }\end{array}$ & $\begin{array}{c}\text { Standard } \\
\text { error } \\
\text { mean }\end{array}$ \\
\hline $\begin{array}{l}\text { Post-test } \\
\text { proficiency }\end{array}$ & & & & \\
$\quad$ Control & 62 & 10.79 & 4.04 & 0.51 \\
Experimental & 62 & 21.96 & 3.06 & 0.40 \\
\hline
\end{tabular}

other words, it can be concluded that using multimedia in teaching English leads to effective language learning.

\section{The Results of Posttest on Attitudes toward Language Learning}

To investigate the effect of multimedia on student's attitudes, the means of the both groups in the post-test were calculated. As Table 10 shows, the mean scores of attitudes level across participants in control and experimental groups are different: control $(M=11.91, S D=2.12)$, experimental $(M=30.64$, $S D=2.81$ ). As table shows, experimental groups have higher attitudes level than control groups in posttest.

As the results of independent-samples $t$-test shows (see Table 11), there is a statistically significant difference between experimental and control groups $(t=-41.86, p<.01)$. The effect size calculated via Cohens' $d$ was found to be 7.52 which is a large value according to Cohens' index value. In other words, it can be said that using multimedia in teaching English is more effective than using traditional methods of teaching.

\section{The Results of Posttest on L2 Anxiety}

To investigate the effect of multimedia on student's anxiety, the means of the both groups in the post-test were calculated. As Table 12 shows, the mean scores of anxiety level across participants in control and experimental groups are different: control $(M=13.43, S D=2.77)$ and experimental $(\mathrm{M}=11.91$, $\mathrm{SD}=2.12)$.

Table 9. Independent samples t-test showing the results of post-test on English proficiency

\begin{tabular}{lccccc}
\hline & t & df & $\begin{array}{c}\text { Sig. } \\
\text { (2-tailed) }\end{array}$ & $\begin{array}{c}\text { Mean } \\
\text { difference }\end{array}$ & $\begin{array}{c}\text { Standard } \\
\text { error } \\
\text { difference }\end{array}$ \\
\hline $\begin{array}{l}\text { Post-test } \\
\text { proficiency }\end{array}$ & -16.97 & 122 & 0.00 & -11.17 & 0.65 \\
\hline
\end{tabular}

Table 10. Descriptive statistics of attitudes across control and experimental groups in post- test

\begin{tabular}{lllll}
\hline & $\mathbf{N}$ & Mean & $\begin{array}{c}\text { Standard } \\
\text { deviation }\end{array}$ & $\begin{array}{c}\text { Standard } \\
\text { error } \\
\text { mean }\end{array}$ \\
\hline $\begin{array}{l}\text { Post-test } \\
\text { attitudes } \\
\text { Control }\end{array}$ & 62 & 11.91 & 2.12 & \\
$\quad \begin{array}{l}\text { Experimental } \\
62\end{array}$ & 30.64 & 2.81 & 0.26 \\
\hline
\end{tabular}

Table 11. Independent samples t-test showing the results of post-test on student's attitudes in control and experimental group

\begin{tabular}{lccccc}
\hline & t & df & $\begin{array}{c}\text { Sig. } \\
\text { (2-tailed) }\end{array}$ & $\begin{array}{c}\text { Mean } \\
\text { difference }\end{array}$ & $\begin{array}{c}\text { Standard } \\
\text { error } \\
\text { difference }\end{array}$ \\
\hline $\begin{array}{l}\text { Post-test } \\
\text { attitudes }\end{array}$ & -41.86 & 122 & 0.00 & -18.72 & 0.44 \\
\hline
\end{tabular}


As the results of independent-samples $t$-test shows, there is a statistically significant difference between groups $(t=3.41, p<.01)$. The effect size calculated via Cohens' $d$ was found to be. 61 which is medium according to Cohens' index value. As table 13 shows, using multimedia in teaching English is tend to reduce L2 learning anxiety.

\section{The Findings of Students' Interview}

A semi-structured interview was conducted with four students of the experimental groups at the end of the semester. This interview was used to discuss the participants' levels of motivation and anxiety, and any changes in their feelings and perceptions about the interactions in which they had participated employing MTs. The questions of the interview were composed by the researchers. All four students stated that they indeed became more interested, motivated, and therefore prone to learn when their teacher used some form of technology.

All students believed that multimedia teaching facilitated their learning of English. One of the students said: "I agree with the use of multimedia materials. By using these techniques, I feel more attached to the real world, communicatively. Other stated," Using multimedia materials will progress my knowledge, I would be able to pass English course with motivation".

Another student articulated: "I felt very enthusiastic towards multimedia teaching that would help me enhance my learning process and skills".

One of them stated: "Multimedia teaching assisted me in making English language learning interesting and enjoyable".

The other one said: "In traditional English class, I did not have enough attention to materials, but in MT class I'm interested in following the process of teaching and I comprehend to all points".

Still another one mentioned:" In MT class, I don't understand the passing of the class time, but in traditional

Table 12. Descriptive statistics of anxiety level across control and experimental groups in post-test

\begin{tabular}{lcccc}
\hline & N & Mean & $\begin{array}{c}\text { Standard } \\
\text { deviation }\end{array}$ & $\begin{array}{c}\text { Standard } \\
\text { error } \\
\text { mean }\end{array}$ \\
\hline $\begin{array}{l}\text { Post-test } \\
\text { anxiety }\end{array}$ & & & & \\
$\quad$ Control & 62 & 13.4355 & 2.77844 & 0.25299 \\
Experimental & 62 & 11.9194 & 2.12169 & 0.26946 \\
\hline
\end{tabular}

Table 13. Independent samples t-test showing the results of post-test on student's anxiety

\begin{tabular}{lccccc}
\hline & t & df & $\begin{array}{c}\text { Sig. } \\
\text { (2-tailed) }\end{array}$ & $\begin{array}{c}\text { Mean } \\
\text { difference }\end{array}$ & $\begin{array}{c}\text { Standard } \\
\text { error } \\
\text { difference }\end{array}$ \\
\hline $\begin{array}{l}\text { Post-test } \\
\text { anxiety }\end{array}$ & 3.414 & 122 & 0.001 & 1.51613 & 0.44408 \\
\hline
\end{tabular}

class the class time is boring”. She continued: "I think I feel greater satisfaction watching large pictures than squinting at smaller images from traditional teaching forms."

As a conclusion, the students believed that they were more motivated when using computers, and learning enhanced when teacher integrated multimedia materials to class instruction. They regarded technology and the tools it provided as having a facilitative effect on their performance.

\section{DISCUSSION AND CONCLUSIONS}

As stated earlier, technology has gained a vital status in fulfilling the prerequisites of the new education system in teaching English with its specific focus on communication in the official schools in Iran. Nevertheless, there is a dearth of research attesting to the technological dimension of English language classes in Iran under the influence of CLT integration in public schools. This study aimed at providing empirical evidence for the current state of technology use in English language classes of high schools. In particular, it probed the impact of MT on enhancing L2 learning attitudes, diminishing L2 anxiety, and improving L2 achievement.

The findings substantiated the facilitative role of MTs in promoting motivational and emotional facets of L2 learning as well as L2 learning itself. This finding coincides with previous research. As Hanson (1995) and ChanLin et al (2006) have pointed out that using technology in teaching English will raise student's motivation, diminish their debilitative feelings, and increase the chances of attaining effective learning. This finding is also in line with identical research in L2 domain (Rostami, Akbari, \& Ghanizadeh, 2015, Ghanizadeh \& Razavi, 2015, Razavi, Ghanizadeh, \& Akbari, 2016). In addition, Reynolds, Treharne, and Tripp (2003) demonstrated the effectiveness of ICT use in raising students' motivation and attitudes towards science. Furthermore, according to Marzban (2010), one of the most important aspects of using multimedia technologies in the classroom is that learners are free from anxiety and there is no peer pressure which inhibits them from language learning.

On this era, Iranian EFL educators are taking major steps towards utilization of MT in educational environments. With daily development of MTs, instructors confront with more challenging responsibilities in teaching. Teachers should first determine what results they are attempting to accomplish and after that select well-suited elements for these outcomes. Hence, for effective utilization of MTs, teachers should first know the exact needs of the learners. Teachers can incorporate MTs into their classroom by detecting each student's individual needs learning styles, coordinating teaching methods to learners' multimedia learning for troublesome tasks, reinforcing weaker learners through access to multimedia learning by making tasks less demanding (Pourhosein Gilakjani \& Ahmadi, 2011). In other words, MTs can create a multiple learning opportunities for learners to improve their learning effectively.

Teacher should be cognizant that multimedia that is effective in learning and teaching doesn't merely involve using multiple media together, but implementing media 
reflectively in ways that take advantage of the characteristics of each individual medium and generalize it to learning and teaching experiences. Teachers should first decide upon the objectives and their teaching approach and only then opt for the type of technology which best suits each learning occasion. Subsequently, they should ensure that the multimedia elements are synchronized and fitted properly in line with learning objectives and students' needs and preferences. To sum up, the findings of the present study may help teachers to take the necessary steps to change learners' negative attitudes and to foster their motivation using technology in a certain manner. Additional research is required to determine which multimedia technologies have greatest impact on learners' motivation and their achievement.

\section{REFERENCES}

Acha, J. (2009). The effectiveness of multimedia programmes in children's vocabulary learning. British Journal of Educational Technology, 40(1), 23-31.

Al-Seghayer, K. (2001). The effect of multimedia annotation modes on L2 vocabulary acquisition: A comparative study. Language Learning and Technology, 5(1), 202-232.

Astleitner, H., \& Hufnagl, M. (2003). The effects of situation-outcome-expectancies and of ARCS-strategies on self-regulated learning with Web-lectures. Journal of Educational Multimedia and Hypermedia, 12(4), 361-376.

Atiyyat, I. (1995). The effect of computer assisted instruction upon tenth grade students' mastering of English vocabulary. Unpublished Masteral thesis. University of Jordan, Jordan.

Azizizadeh, S. (2007). Review of effectiveness of creativity training on improvement of entrepreneurial attitude in unemployed people in Tehran City. Unpublished Masteral thesis, Field of occupational consultation.

Bacon, S., \& Finnemann, M. (1990).A study of the attitudes, motives, and strategies of university foreign language students and their disposition to authentic oral and written input. The Modern Language Journal, 74, 459-473.

Bagui, S. (1998). Reasons for increased learning using multimedia.Journal of Educational Multimedia and Hypermedia, 7, 3-18.

Brooks, D. W. (1997). Web-teaching: A guide to designing interactive teaching for the World Wide Web. New York: Plenum.

ChanLin, L., Hong, J., Horng, J., Chang, S., \& Chu, C. (2006). Factors influencing technology integration in Teachers' perceptions of the use of multimedia in teaching English in official and non-official language settings teaching: A Taiwanese perspective. Innovations in Education and Teaching International, 143(1), 57-68.

Chen, G., \& Fu, X. (2003).Effects of multimodal information on learning performance and judgment of learning. Journal of Educational Computing Research, 29(3), 349-362.

Cuban, L. (2001). Teachers and machines: The classroom uses of technology. New York: Longman.
Dale, E. (1969). Audio-visual methods in teaching. New York: Dryden.

David, E., \& Dan, B. (2002).A collaborative and interdisciplinary computer animation. The MIT Press Course Leonardo, 35(1), 83-86.

Davis, B. G. (1993). Tools for Teaching. Jossey-Bass Inc., San Francisco: California.

Dornyei, Z., \& Csizer, K. (2002). Some dynamics of language attitudes and motivation: Results of a longitudinal nationwide survey. Applied Linguistics, 23(4), 421-462.

Fadel, C. (2008). Multimodal Learning Through Media: What the Research Says. San Jose, CA: Cisco Systems.

Fletcher, J. D. (2003). Evidence for learning from technology-assisted instruction. In Technology applications in education: A learning view, eds. H. O’Neil. F. Jr. and R. S. Perez, 79-99.

Ghanizadeh, A., \& Heidarnejad, T. (2015). A cross-contextual analysis of Iranian EFL teachers' attitudes and perceptions of critical thinking. International Journal of Research Studies in Education, 4(4), 27-38.

Ghanizadeh, A., \& Jahedizadeh, S. (2015). An exploration of EFL learners' perceptions of classroom activities and their achievement goal orientations.International Journal of Research Studies in Education, 4(3), 33-45.

Ghanizadeh, A., \& Razavi, A. (2015).The impact of using multimedia in English high school classes on students' language achievement and goal orientation. International Journal of Research Studies in Educational Technology, 4(2), 31-42.

Ghanizadeh, A., \& Razavi, A. (2016). Teachers' perceptions of the use of multimedia in teaching

English in official and non-official language learning settings. International Journal of Research Studies in Educational Technology, 18(2), 24-33.

Ghanizadeh, A., Razavi, A., \& Jahedizadeh, S. (2015). Technology-enhanced language learning: A review of resources and upshots. International Letters of Social and Humanistic Sciences, 54, 73-87.

Ghanizadeh, A., \& Rostami, S. (2015). A Dörnyei-inspired study on second language motivation: a cross-comparison analysis in public and private contexts. Psychological Studies, 60 (3), 292-301, DOI: 10.1007/s12646015-0328-4.

Hahne, A. K., Benndorf, R., Frey, P., \& Herzig, S. (2005). Attitude towards computer-based learning: determinants as revealed by a controlled interventional study. Medical Education, 39(9), 935-943.

Hardré, P., Sullivan, D., \& Crowson, H. (2009). Student characteristics and motivation in rural high schools. Journal of Research in Rural Education, 24(16), 1-19.

Harper, B., \& Hedberg, J. (1997).Creating motivating interactive learning environments: A constructivist view. $\mathrm{Pa}-$ per presented at ASCILITE December, 7-10.

Hanson-Smith, E. (1999). Classroom practice: Using multimedia for input and interaction in CALL environments. In E. Hanson-Smith (Ed.), CALL environments: research, practice, and critical issues (pp. 189-215). Alexandria, VA: TESOL. 
Hashemi, M., \& Najafi, V. (2011) Using blogs in English language writing classes. International Journal of Academic Research, 3 (4), 599-604.

Hayati, F., \& Mohemdi, A. (2010). The Effect of films with and without subtitles on listening comprehension of EFL intermediate students. International Journal of Instructional Media, 37(3), 301-313.

Horwitz, E. K. (2001). Language anxiety and achievement. Annual Review of Applied Linguistics, 21, 112-126.

Hoskins, S. L., \& van Hooff, J. C. (2005) Motivation and ability: which students use online learning and what influence does it have on their achievement? British Journal of Educational Technology, 36(2), 177-192.

Huang, C. (2012). The study of the efficiency of applying animation multimedia for assistance of teaching of physics and chemistry in junior high school. Unpublished Master's dissertation, Changhua University Hsinchu, Taiwan.

JafariHajati, O. (2006). Assessment of the design of smart schools in high schools of Tehran. Masteral thesis, Department of Psychology, University of Teacher Education.

Jahedizadeh, S., Ghanizadeh, A., \& Ghonsooly, B. (2016). The role of EFL learners' demotivation, perceptions of classroom activities, and mastery goal in predicting their language achievement and burnout. Asian-Pacific Journal of Second and Foreign Language Education, 1-16. DOI 10.1186/s40862-016-0021-8.

Joseph, R., \& Nassar, (1995). Dual coding as a possible explanation for the effects of multimedia on learning. Georgia Institute of Technology, Georgia.Journal of Language and Literacy, 33(3), 211-239.

Keller, J. M., \& Suzuki, K. (2004). Learner motivation and e-Learning design: a multi-nationally validated process. Journal of Educational Media, 29(3), 229-239.

Khodadady, E., \& Ghanizadeh, A. (2011). The impact of concept mapping on EFL learners' critical thinking ability. English Language Teaching, 4(4), 49-60.

Kozma, R. (1991). Learning with media. Review of Educational Research, 61, 179-211.

Lafford, P. A., \& Lafford, B. A. (1997).Learning language and culture with the Internet. In R. M. Terry (Ed.), Technology-enhanced language learning (pp. XX-XX). Lincolnwood, IL: The National Textbook Company.

Larkin, D., \& Simon, H. A. (1987). Why a diagram is (sometimes) worth ten thousand words. Cognitive Science, $11(1), 65$.

Lee, L. (2002). Going beyond classroom learning: Acquiring cultural knowledge via online newspapers and intercultural exchanges via online chat rooms. CALICO Journal, 16(2). 110-126.

Lin, H., \& Chen, T. (2007). Reading authentic EFL text using visualization and advance organizers in a multimedia learning environment.Language Learning and Technology, 11(3), 83-106.

Margie, J., \& Liu, M. (1996).Introducing interactive multimedia to young children: A case study of how two-yearsolds interact with the technology. Educational Resources Information center.
Massa, L. J., \& Mayer, R. E. (2006). Testing the ATI hypothesis: Should multimedia instruction accommodate verbalizer-visualizer cognitive style? Learning and Individual Differences, 16, 321-336.

Mayer,A.E. Plass, J.L., Chun D.M.\&Leutner,D.(1998). Supporting visual and verbal learning preferences in a second-language multimedia learning environment, Journal of Educational Psychology, 90, 25-36.

Mayer, A. E. (2003). Elements of a science of e-learning. Journal of Educational Computing Research, 29(3), 297-313.

Mayer, R. E. \& Moreno,R. (1998). A split-attention effect in multimedia learning: Evidence for dual processing systems in working memory. Journal of Educational Psychology 90: 312-320.

Moreno, R., \& Mayer, R. (2007). Interactive multimodal learning environments. Educational Psychological Review, 19, 309-326.

Mueller, S. M. (1980). Delivering multimedia teaching modules via the Internet. Innovations in Education and Training International, 36(1), 11-16.

Murphy, K. L., Mahoney, S. E., Chen, C. Y., Mendoza-Diaz, N. V. \& Yang, X. (2005). A constructivist model of mentoring, coaching, and facilitating online discussion. Distance Education, 26(3) 341-366.

Prensky, C.G. (2001). Modality effects and the structure of short-term verbal memory. Memory \& Cognition, 17(4), 398-422.

Pourhosein Gilakjani, A., \& Ahmadi, S. M. (2011). Multimedia and its effect on the quality of English language teaching. Culture, English Language Teaching and Literature, 11(1). 14-35.

Ramaiah, C. K. (1998). Multimedia systems in libraries and their applications. DESIDOC Bulletin of Information Technology, 18 (6), 25-40.

Rana, P.S. (2013). Education and the use of technology. Republica The Week, 12.

Razavi, A., Ghanizadeh, A., \& Akbari, O. (2016). Teachers' perceptions of the use of multimedia in teaching English in official and non-official language learning Settings. International Journal of Research Studies in Educational Technology, 5 (1), 91-104.

Rostami, S., Akbari, O., \& Ghanizadeh, A. (2015). The effect of smart school programs on EFL reading comprehension in an academic context. International Journal of Research Studies in Educational Technology, 4(1), 1-10.

Shah, C., \& Freedman, C. (2003). Teachers discovering computers: Integrating technology and digital media in the classroom (4 ${ }^{\text {th }}$ Ed.). Boston: Thomson Course Techno.

Smith, S. M., \& Woody, P. C. (2000).Interactive effect of multimedia instruction and learning styles.Teaching of Psychology, 27(3), 220-223

Sun, Y., \& Dong, O. (2004). An experiment on supporting children's English vocabulary learning in multimedia context. Foreign Languages \& Literature, 17(2), 131-147.

Shuell, T. J., \& Farber, S. L. (2001). Students' perceptions of technology use in college courses. Journal of Educational Computing Research, 24, 119-138. 
Song, S. H., \& Keller, J. M. (2001). Effectiveness of motivationally adaptive computer-assisted instruction on the dynamic aspects of motivation. Educational Technology Research and Development, 49(2), 5-22.

Taguchi, T., Magid, M., \& Papi, M. (2009). The L2 motivational self system among Japanese, Chinese and Iranian learners of English: A comparative case study. In Z. Dörnyei\& E. Ushioda (Eds.), Motivation, language identity and the L2 self (pp.66-97). Clevedon, UK: Multilingual Matters.

Thorton, P., \& Dudley, A. (1996). The CALL environment: An alternative to the language lab. CAELL Journal, 7(4), 29-34.

Wang, C. R. (2008). A comparative study on the traditional model of English teaching and multimedia computer aided English teaching. Journal of Hunan First Normal College, 8 (3), 56-58.

Warschauer, M.: (1997) Computer-mediated collaborative learning: Theory and practice, Modern Language Journal, 81(4), 470-481.

Warschauer, M., \& Healey, D. (1998). Computers and language learning: An overview, Language Teaching, 31 (1), 57-71.

Wasley, P. (2006). Underrepresented students benefit most from 'engagement.' The Chronicle of Higher Education, 53 (13), 39
Weyers, J. R. (1999). The effects of authentic video on communicative competence. The Modern Language Journal, 83(3), 339-349.

Woody, J. (2000). Teachers' perceptions of computer needs. Journal of Research on Computing in Education, 23(4), 475-496.

Xie, T. (2002). Using Internet relay chat in teaching Chinese. Computer Assisted Language Instruction Consortium, 19(3), 513-524.

Yang, D. C., \& Fang, Y. F. (2008). Promoting sixth graders' number sense and learning attitudes via technology-based environment. Educational Technology \& Society, 13(4), 112-125.

Zafarmand, A., Ghanizadeh, A., \& Akbari, O. (2014).a structural equation modeling of EFL learners' goal orientation, meta cognitive awareness, and self-efficacy. Advances in Language and Literary Studies, 5 (6), 112-124.

Zemke, Z. Y., \& Espinoza, S. (2001). Relationship among computer self-efficacy, attitudes toward computers, and desirability of learning computing skills. Journal of Research and Computing in Education, 30(4), 420-438.

Zhao, Y., \& Cziko, G. A. (2001). Teacher adoption of technology: A perceptual control theory perspective. Journal of Technology and Teacher Education, 9(1), 5-30. 